\title{
Challenges faced by Women Entrepreneurs : A Case study TandoAllahyar District.
}

\author{
MsAlbeenaMirza \\ Assistant Professor ,Department of Economics University of Sindh Jamshoro \\ NajmaShaikh \\ Assistant Professor- Deptt:of Economics, University of Sindh jamshoro \\ Aisha Bashir Shah \\ Assistant Professor-IBA-University of Sindh jamshoro \\ Hisam-u-ddinShaikh \\ Lecturer \\ Deptt:of Mathematics \\ Shah Abdul Latif University KhairpurMirs
}

\begin{abstract}
The research investigates the domestic violence against women in TandoAllahyar District-Sindh Pakistan. Data were collected through survey from 200 respondents. Data were analyzed by using SPSS-21 version. It was revealed that most of the surveyed women were quiet depressed and their male counterparts not working but they are solely depending on women work in SMEs. It was further revealed that the rural women is less confident and their husbands were always given them hard time once they are exposing themselves to outside the boundaries of the house
\end{abstract}

Key Words: Challenges, faced, Women entrepreneur.

\section{Introduction}

The term 'honor murdering' was presented by a Dutch researcher from a Turkish foundation in 1978 to separate such killings from different sorts of executing in families and groups. Human Rights Watch states, "Honor killings are demonstrations of retribution, generally demise, submitted by male relatives against female relatives who are held to have brought disrespect upon the family."

We as a whole realize that honor killings are a standout amongst the most mentally intricate, sociologically confused, ethically upsetting and lawfully difficult brutal violations against humankind. Such wrongdoings have been going on all through history everywhere throughout the world in numerous groups, nations and societies. In honor killings, the casualties are for the most part ladies and the killers are generally men, whether fathers, siblings, spouses or children.

As indicated by human rights specialists, the adherents of all beliefs, including Hinduism, Islam, Judaism and Christianity, have utilized a religious appearance to submit honor killings. The specialists clarify that honor killings don't have "any unequivocal association with religion by any means". Honor killings have been honed before any real religion appeared.

The UN Population Fund (UNFPA) gauges that upwards of 5,000 young ladies and ladies have been killed for the sake of honor by their relatives as of late. This is sadly simply hard measurements. The genuine number could be impossible to say and significantly more than this. Reprieve International claims that the occurrence of honor killings is expanding every year. As indicated by the Human Rights Commission of Pakistan (HRCP), around 1,957 occurrences of honor killings had been recorded in the course of recent years and the vast majority of them had happened in light of claimed extramarital relations. Through measurements gave by the Marvi Rural Development Organization (MRDO), working in Sindh, around 270 cases have been enlisted in the earlier year. Sindh and Balochistan are the main spots in the nation where the lives of men are likewise taken in honor killings.

The subtle elements of homicides of the ladies decapitated, smoldered to death, stoned to death, wounded, shocked, choked and covered alive for the honor of their families are as brutal as they are disgraceful. Numerous ladies' gatherings in the Middle East and Southwest Asia suspect the casualties are no less than four times the United Nations' most recent figure of around 5,000 passings a year. The vast majority of the casualties are youthful — numerous are adolescents, butchered under an abominable custom that backpedals several years yet now traverses a large portion of the globe. Be that as it may, as I would like to think, men are likewise killed now and again for the sake of honor. It makes one even pitiful to realize that this uncouth practice rises above past confidence, order and significantly sexual orientation.

Through exploration I happened to the perspective that Iraqis, Kurds, Palestinians in Jordan, Pakistan and Turkey show up the most noticeably awful wrongdoers however media opportunities in these nations may over-make up for the mystery that encompasses "honor" killings in Egypt, which untruly asserts there are none, and other Middle Eastern countries in the Gulf and the Levant. Honor wrongdoings long back spread to the UK, Belgium, Russia, Canada and numerous different countries. 
Human rights bunches imagine that honor killings go ahead in the attire of different names in various parts of the world. It accompanies the name of karokari in Pakistan, share passings or lady of the hour smoldering in India, loss of ird in the Bedouin (Middle East) people group and as violations of enthusiasm in Latin America.

Through discourse with various specialists I came to realize that the strategies for completing honor killings change crosswise over various nations. In the southern region of Sindh, where it is frequently alluded to as karokari, the casualty is hacked to death, regularly with the complicity of the group. Among tribal Pashtun people group in Khyber Pakhtunkhwa where the practice is known as tur, and Balochistan in the southwest, the casualty can be hacked, cut, smoldered or shot. In both cases, the practice's name signifies "dark" in the nearby dialects, in reference to the apparent socially unsuitable conduct of the casualties. In crowded Punjab, the killings - more often than not by shooting — are all the more frequently in view of individual choices and completed in private.

Measurements say that inside and out the globe, just a large portion of the killings are by guns, the rest being by throttling or cutting with a blade. The dominant part of ladies are between the ages of 16 and 30 years old. Wherever it is done (east or west), whoever submits it (a sibling or a spouse), or whatever the intention is (honor or desire), the deciding result continues as before: a lady, in 99.9 percent cases, gets to be prey to the misanthrope outlook of a nearby male relative.

The aggregate number of ladies and young ladies who passed on between 2008-2012 because of homicide, honor killings or suicide was 13,583 , as indicated by the Aurat Foundation, a ladies' rights bunch situated in Islamabad. Five of the 10 regions with the most elevated frequency of honor killings are in Sindh, the gathering said in a report distributed in 2013. "A man indicted for the sake of honor is refreshing and hailed, among his group individuals as well as by the individuals who see him in prison," Marri said. "They let him know he's made the best decision. The legislators don't censure this with the goal that they keep votes."

Individuals use karo-kari as an approach to settle question, said Zia Ahmed Awan, a human-rights legal counselor and individual from the Pakistan Bar Council, the country's top legitimate element.

"A man executes his significant other in their own particular house and afterward murders his enemy, saying he was having an illegal association with her," said Awan, who runs Madadgaar, an across the nation helpline for ladies and kids. "That way the foe kicks the bucket and the property debate he had is settled. On the off chance that you have six sisters, you give up one. Indeed, even moms are murdered."

The alleged honor killings of Karo/Kari (dark man/dark lady) is a tribal custom in the Sindh and Pakistan. The term karo (for man) or kari (for lady) is utilized for the individual found as a part of infidelity or wrong sexual relationship as portrayed by nearby uneducated men. The suspicious man can slaughter her blaming for being kari whilst seeing or even subsequent to listening to gossip of the young lady sitting adjacent as man, talking, waling, grinning at, laying down with another man. Albeit both genders are at danger, numerous men escape passing by fleeing or influencing the lady's relatives to acknowledge money, land or then again lady in marriage. Ladies once in a while have any choices. Sadly ladies is offered as a penance to fix the wrong doings of a man. The lady that is being given over (fit as a fiddle of marriage) is not treated with honor. At times she is thought as a horsy whom anybody can fulfill his sexual craving remorselessly blaming and reminding her the status in their family.

Honor KILLING is seen as a piece of religious right (albeit no religion acknowledge it) as a Muslim (man or lady) when discovered liable of infidelity ought to be executed or stoned to death. The Muslim law practice is completely diverse and entangled which includes a large portion of administrative issues, (for example, witnesses, character of witness, scene of wrongdoing, neighborhood and individual reports and so forth) and barely a judge can issue such a capital punishment. Be that as it may, for the sake of honor executing MAN needs to murder and show up under the steady gaze of the court conceding the slaughter. Along these lines his sentence can be decreased or considered subject to group of casualty. On the off chance that the group of casualty are normal or needy individuals they can be paid off or constrained effectively to FORGIVE THE KILLER. Such practice is extremely pitiless and shockingly supported by nearby tribesmen, lawmakers despite the fact that they authoritatively deny such reports and issue explanations yet as a general rule they don't assume their dynamic part to end it. The one justifiable reason is their association in the nearby feslo or jirgo [local tribe courts].

As indicated by a late overview directed by Sindhi daily papers, some 300-400 individuals were killed by honor killings in Sindh consistently. The casualties included around $80 \%$ ladies and $20 \%$ men. Human right Activists trust the figures are truth be told much higher, since most respect killings go unreported. Sindh is one and only of the areas in world where such occurrences happen much of the time.

\section{Information Collection Methodology}

Information were gathered from 200 by utilizing subjective and quantitative techniques were utilized. The subjective techniques included beginning center gathering gatherings that were trailed by the study survey. The study poll was a greater amount of a top to bottom meeting due to the delicate way of the issues and along these lines included open finished inquiries with specific inductions on the sorts of brutality recorded on a quantitative sheet. Information were investigated by utilizing SPSS-21 version.

\section{Results and Discussion}

Pakistan ought to perceive abusive behavior at home as a wrongdoing and authorize strict disciplines for the culprits. Cops and government officials need to consider these violations important and rebuff the guilty parties. Ladies ought to be taught and urged to battle for their rights. Honor wrongdoings are for the most part dedicated by ignorant Muslim men who

\begin{tabular}{|c|c|}
\hline $\begin{array}{l}\text { 2966 | P a g e } \\
\text { A ug u s t } 2016\end{array}$ & $\begin{array}{r}\text { council for Innovative Research } \\
\text { w w w c ir or } 1 \text { d. com }\end{array}$ \\
\hline
\end{tabular}


International Journal of Management and Information Technology trust that Islam obliges them to execute their female relatives for family respect. They ought to be instructed about Islamic teachings.

Table 1. Specific risk situations across a woman in District TandoAllahyar

\begin{tabular}{|l|l|}
\hline Phase & Type of Violence \\
\hline Pre-Birth & $\begin{array}{l}\text { Sex-selective abortion; effects of battering during pregnancy and birth } \\
\text { outcomes }\end{array}$ \\
\hline Infancy & Female infanticide; physical, sexual and psychological abuse \\
\hline Girlhood & $\begin{array}{l}\text { Child marriage; female genital mutilation; physical, sexual and psychological } \\
\text { abuse; incest; child prostitution and pornography }\end{array}$ \\
\hline
\end{tabular}

\section{Survey-2015}

Every year, a large number of young ladies experience female genital mutilation. Female kids are more probable than their siblings to be assaulted or sexually attacked by relatives, by those in positions of trust or control, or by outsiders. In a few nations, when an unmarried lady or pre-adult is assaulted, she might be compelled to wed her aggressor, or she might be detained for carrying out a "criminal" demonstration. Those ladies, who get to be pregnant before marriage might be beaten, shunned or killed by relatives, regardless of the fact that the pregnancy is the consequence of an assault.

After marriage, the most serious danger of viciousness for ladies keeps on being in their own homes where spouses and, now and again, in-laws, may ambush, assault or slaughter them. At the point when ladies get to be pregnant, develop old, or experience the ill effects of mental or physical inability, they are more helpless against assault. Ladies who are far from home, detained or segregated in any capacity are additionally subject to brutal attacks. Amid outfitted clash, ambushes against ladies heighten; including those submitted by both antagonistic and "neighborly" strengths.

\section{Conclusion}

The current research highlighted Challenges faced by Women Entrepreneurs : A Case study TandoAllahyar District. The results shows that women as entrepreneur facing lot challenges like victoms of male counterparts, no market access, low wages and facing social and health problems. Most of the women abused during childhood by their family friends. They find only one consistent risk marker for women: witnessing parental violence as a child or adolescent. Being abused as a child leaves a woman more at risk for revictimization in later life. Meaningful steps to end domestic violence are needed and most importantly, the problem should be removed from the private sphere. It is a critical international problem that affects every community, every work place and every school.

\section{Reference}

1. F.M.Shaikh\&Dr.Anwar Ali Shah (2013) Domestic Violence against women: A Case study of Shikarpur-SindhPAKISTAN Vol-10-N0-1 Winter,2013 International Journal of Business and Public Administration-USA.

2. HamzaAlvi. (2009). Pakistani women in a changing society Human Rights Commission of Pakistan - 1999 Report.Economic Survey of Pakistan, 10.

3. J.A. Rehman. (1998). The legal rights of women in Pakistan: Theory \& Practice, p.9. Nafisa Shah. (1993). Of Female Bondage.News time, January, p.44.

4. Nafisa Shah. (1998). A story in black: Karo Kari Killings in upper Sindh, REUTER Foundation Paper 100 ford 1998 p.5 Newsline, April, p.18.

5. Simi Kamal \&Asma Khan. (1997). A study of the interplay of formal and customary laws on woman, Vol. 1, p ii.Somnath Sen. (1992). 'Military Expenditure Data for Developing Countries: Methods and Measurement', in Geoffrey Lamb and ValerianaKallab (ed.), Military Expenditure and Economic Development: A Symposium on Research Issues, Discussion Paper no.185, The World Bank, Washington, D.C. Notes Note 1. The UN Declaration on the Elimination of violence against women, General Assembly Resolution, December, 1993 Note 2.

6. Simi Kamal, Asma Khan: A study of the interplay of formal and customary laws on woman, Vvol 1, $1997, p$ ii Note 3.

7.. Aman. S. Kitchen Murders: why only women? The News 20th June 1992 Note 4. Human Rights Commission of Pakistan: State of Human Rights in 2001 Note 5.

8. Human Development in South Asia 2000: The Gender Question Mebub-ul-Haq Human Development Center p.92 Note 6.

09. J.A. Rehman, The legal rights of women in Pakistan: Theory \& Practical, 1998, p.9 Note 7. Nafisa Shah: A story in black: Karo Kari Killings in upper Sindh, REUTER Foundation Paper 100 ford 1998 p.5 Note 8. Newsline, April 1998, p.18 
I nternational Journal of Management and Information Technology

10. Economic and Social Council. Commission on Human Rights, Subcommission on Prevention of Discrimination and Protection of Minorities. Preliminary report of the Special Rapporteur on traditional practices affecting the health of women and children.Mrs. HalimaEmbarekWarzazi, Document n E/CN.4/Sub.2/1995/6, 20 July 1995.

11. ECPAT, Declaration of Stockholm on Commercial Sexual Exploitation of Children, August 1996.

EG-S-VL (97)1, Final report of activities of the EG-S-VL including a Plan of Action for combating violence against women. Group of specialists for combating violence against women, Strasbourg, 25 June 1997.

12. Ellsberg M, R Peña, A Herrera, J Liljestrand, A Winkvist. The reality of battered women in .

Ellsberg M, Liljestrand J, Winkvist A, The Nicaraguan Network of Women against Violence: Using Research and Action for Change, Reproductive Health Matters, № 10, November 1997.

13. Epstein $\mathrm{H}$, The intimate enemy: gender violence and reproductive health, Panos Briefing $\mathrm{n}^{\circ} 27$, march 1998, http://www.oneworld.org/panos/briefing/genviol.html European Commission, Communication on trafficking in women for the purpose of sexual exploitation. Summary. http://europa.eu.int, 1999.

14. Fikree FF, Bhatti LI. Domestic violence and health of Pakistani women. International Journal of Obstetrics \&Gynaecology, May 1999.

15. Flitcraft A, From Public Health to Personal Health: Violence against Women across the Life Span, editorial Annals of Internal Medicine, November 1995, Volume 123, $\mathrm{n}^{\circ} 10$.

16. Flitcraft A, Violence, Values and Gender, JAMA, June 17, 1992-vol. 267, nº 23.

Fluery, S. Politica Social, Exclusion y Equidad en Venezuela durante los anos 90. Balance y perspectivas. Promoted by Fonvis, Indes-BID, Cendes and Caracas, May 1998.

17. Ford NJ, Kittisuksathit S. Destinations unknown: the gender construction and changing nature of the sexual expressions of Thai youth. AIDS Care. 1994,6(5):517-31.

18. Fundación Mexicana para la Planeacion Familiar (MEXFAM), Information on Violence against women, Mexico, 1998.

19. Gage A, Njogu W. Gender inequalities and demographic behaviour. Ghana/Kenya. The Population Council New York. 1994.

20. Gazmarian JA, Lazorick S, Spitz AM, et al. Prevalence of violence against pregnant women. JAMA 1996;275(24):1915-20; Campbell JC. Addressing battering during pregnancy: reducing low birth weight and ongoing abuse. SeminPerinatol 1995;19(4):301-06.

21. Gazmarian JA, Adams MM, Saltzmann LE, Johnson CH, Bruce C, Marks JS, Zahniser SC, PRAMS Working Group, The relationship between pregnancy intendedness and physical violence in mothers of newborns, Obstetrics and Gynecology, vol. 85, n 6, June 1995. 